\title{
Biodiversity offsetting and restoration under the European Union Habitats Directive: balancing between no net loss and deathbed conservation?
}

\author{
$\underline{\text { Hendrik Schoukens }}^{1}$ and $\underline{\text { An Cliquet }}^{1}$
}

\begin{abstract}
Biodiversity offsets have emerged as one of the most prominent policy approaches to align economic development with nature protection across many jurisdictions, including the European Union. Given the increased level of scrutiny that needs to be applied when authorizing economic developments near protected Natura 2000 sites, the incorporation of onsite biodiversity offsets in project design has grown increasingly popular in some member states, such as the Netherlands and Belgium. Under this approach, the negative effects of developments are outbalanced by restoration programs that are functionally linked to the infrastructure projects. However, although taking into consideration that the positive effects of onsite restoration measures leads to more leeway for harmful project development, the EU Court of Justice has recently dismissed the latter approaches for going against the preventative underpinnings of the EU Habitats Directive. Also, the expected beneficial outcomes of the restoration efforts are uncertain and thus cannot be relied upon in an ecological assessment under Article 6(3) of the Habitats Directive. Although biodiversity offsets can still be relied upon whenever application is being made of the derogation clause under Article 6(4) of the Habitats Directive, they cannot be used as mitigation under the generic decision-making process for plans and programs liable to adversely affect Natura 2000 sites. We outline the main arguments pro and contra the stance of the EU Court of Justice with regards to the exact delineation between mitigation and compensation. The analysis is also framed in the ongoing debate on the effectiveness of the EU nature directives. Although ostensibly rigid, it is argued that the recent case-law developments are in line with the main principles underpinning biodiversity offsetting. Opening the door for biodiversity offsetting under the Habitats Directive will certainly not reverse the predicament of the EU's biodiversity. A reinforcement of the preventative approach is instrumental to avert a further biodiversity loss within the European Union, even if it will lead to additional permit refusals for unsustainable project developments.
\end{abstract}

Key Words: biodiversity offsetting; Briels case; compensation; ecological restoration; Habitats Directive; mitigation

\section{INTRODUCTION}

The concept of compensation for ecological damage or biodiversity offsetting has risen to the fore as one of the most prominent policy approaches to ensure that development with adverse ecological impacts does not lead to a net loss of nature conservation interests (Calvet et al. 2015, Lapeyre et al. 2015). The Business and Biodiversity Programme (BBOP) of the IUCN now defines biodiversity offsets as "measurable conservation outcomes resulting from actions designed to compensate for significant residual adverse biodiversity impacts arising from project development after appropriate prevention and mitigation measures have been taken" (BBOP 2012:13). The goal of biodiversity offsets or compensation is to achieve no net loss and preferably a net gain of biodiversity on the ground with respect to species composition, habitat structure, ecosystem function and people's use, and cultural values associated with biodiversity. If implemented and enforced in an effective manner, it holds the promise of striking the right balance between achieving nature conservation targets and facilitating sustainable development (Hough and Robertson 2009, Pilgrim and Bennun 2014, Froger et al. 2015, Maron et al. 2015). The core principle underpinning biodiversity offsets, and compensation and restoration more generally, is that of a "no net loss" of biodiversity and if possible, a "net gain" (BBOP 2012).

Also within the European Union, the idea of "impact neutrality" (McGillivray 2012) has been embraced as one of the prime instruments to meet existing conservation targets without impeding economic development. However, although the existing rules of the EU environmental legislation, such as the EU nature directives (European Commission 1992, European Parliament and Council of the European Union 2009), the Environmental Impact Assessment Directive (European Parliament and Council of the European Union 2011), and the Environmental Liability Directive (European Parliament and Council of the European Union 2004) already allow restoration measures to be taken into account to some extent, a generic and coherent approach toward biodiversity offsetting is currently lacking at the EU level (Reese 2015). To achieve the EU 2020 biodiversity objectives (EC 2011:12), the European Commission pledged to develop an initiative under Target 2 of the Biodiversity Strategy "to ensure there is no net loss of ecosystems and their services (e.g., through compensation and offsetting schemes)"(EC 2011). In this respect, the European Commission had already commissioned several preparatory studies (Tucker et al. 2013), which were later used as a basis for an EU-wide public consultation on the topic of the EU no net loss initiative.

In recent years, the quest for leeway in the context of the existing protection rules linked to the Natura 2000 Network has placed biodiversity offsetting and compensation at the heart of the ongoing debate on the effectiveness of the EU nature directives. The EU nature directives have achieved some remarkable successes, such as stemming the demise of several threatened bird species (Donald et al. 2007, Sanderson et al. 2016) and fostering the local recovery of large carnivore species (Chapron et al. 2014). However, the general outlook for the EU's biodiversity remains bleak. Nature is still being eroded overall and the pressures continue. For the whole of the EU, only $16 \%$ of the protected habitats and $23 \%$ of the protected species are currently at a favorable conservation status (EEA 2015). 
Although the limited scope of the EU nature directives (Cliquet et al. 2009, Verschuuren 2010, Schoukens 2015) and the lax application and poor enforcement of the protection rules on the ground (López-Bao et al. 2015) are to be blamed for the limited progress so far, an increasing number of business people, farmers, and politicians also point to the alleged stringency of the existing protection rules. Under the critics' view, the exclusive focus on ecological considerations in the protection scheme, capable of completely prohibiting or at least severely restricting landowners from developing their property, does not provide any tangible incentives for nature conservation or restoration on a larger scale (Kistenkas 2013, Borgström and Kistenkas 2014).

To overcome or avoid possible deadlock scenarios for new development in the vicinity of Natura 2000 sites, some member states have implemented more integrated and flexible permit strategies (Frins and Schoukens 2014, Zijlmans and Woldendorp 2014). In the Netherlands for instance, on-site habitat creation, restoration, and enhancement measures are increasingly designed into project developments (Verschuuren 2010). Henceforth, the on-site actions ensure that the overall impact (i.e., the ecological footprint) of the purported projects would no longer compromise the preservation of the affected Natura 2000 sites. As a result of that, more leeway would be offered in the context of the decisionmaking procedures (Zijlmans and Woldendorp 2014).

Although a more widespread incorporation of active restoration actions in project design might be important for achieving the no net loss goal, it also gives rise to additional concerns. The growing use of what could be labeled as "on-site offsets" obviously provides the permit issuing instances with a greater margin to authorize unsustainable projects, which would exacerbate the ongoing biodiversity decline. Moreover, given the unfavorable status of biodiversity in the EU and the current doubts surrounding the effectiveness of habitat creation and restoration efforts (Moreno-Mateos et al. 2012, 2015, Curran et al. 2014, Van Teeffelen et al. 2014), it remains questionable whether the latter approach would not undermine the preventative approach underpinning the EU nature directives (Schoukens 2014).

By analyzing the applicable case law, regulatory instruments, policy documents, and legal literature, we try to analyze the topic of on-site restoration actions in a development scenario within the regulatory context of the EU nature directives.

\section{EUROPEAN UNION NATURE PROTECTION RULES AND ECONOMIC DEVELOPMENT}

\section{The basic protection rules}

The Habitats Directive constitutes the bedrock of EU nature conservation law and is comprised of two pillars. The first pillar requires the member states to conserve or restore the threatened and endangered habitats and species, which are listed in Annexes I and II of the Habitats Directive, by the establishment of an ecological network of protected areas. Along with the special protection areas (SPAs), selected under the Birds Directive, the special conservation areas (SACs) make up the Natura 2000 network, which at present comprises approximately $18 \%$ of the EU's land area. Article 6 of the Habitats Directive lays down the basic conservation and protection duties (Verschuuren 2010, EC 2000).
The procedural and substantive assessment rules contained by Article 6(3) and (4) of the Habitats Directive set out the specific procedures to be followed in respect to a plan or project that is likely to have a significant effect on Natura 2000 (EC 2001). The said provisions are often referred to as the "appropriate assessment-test." Before a plan or project can be approved in the vicinity of a Natura 2000 site, a thorough appropriate assessment needs to be carried out (EC 2000, ECJ 2004). This exclusively scientifically based analysis needs to assess whether the plan or project does not fundamentally compromise the conservation objectives of the affected Natura 2000 site (ECJ 2005). The competent national authorities can only authorize plans or projects whenever conclusive evidence is produced that they will not adversely affect the integrity of the Natura 2000 site. According to the case law of the European Court of Justice (ECJ), this is the case in which no scientific doubt remains as to the absence of such affects, which strongly hints at a strict application of the precautionary principle (Frins and Schoukens 2014).

To determine whether a plan or project can give rise to significant effects, the impact on the site-specific conservation objectives will be determinative. Hence, less leeway for new developments will be available for Natura 2000 sites that are currently at an unfavorable conservation status and therefore require stricter scrutiny. As a matter of principle, unsustainable development projects will have to be rejected if they do not pass this significance test (EC 2000, ECJ 2004, Scott 2012, ECJ 2013). Under Article 6(4) development can still go ahead, provided that there is no alternative solution, that it is necessary for imperative reasons of overriding public interest, and all compensatory measures necessary to ensure the overall coherence of the Natura 2000 network are taken (EC 2007/2012, McGillivray 2012). These compensatory measures are tagged as offsets in most publications that compile and compare regulations aimed at achieving no net loss (e.g., ten Kate and Crowe 2014).

The second pillar of the Habitats Directive, which is contained in Articles 12 and 16, lays down a strict protection regime for threatened species included in Annex IV. This protection scheme also has to be applied outside areas with a protected status under EU or national law (EC 2007). Article 16(1) of the Habitats Directive grants some margin to bypass the strict protection whenever the development observes a set of strict derogation conditions (Schoukens and Bastmeijer 2015). Although the application of the strict protection rules might also interfere with economic development, even outside the context of protected areas, this second pillar is not addressed in detail in the subsequent analysis. Still, given the major similarities between both pillars, it can be entertained that the subsequent findings are also applicable in the context of the strict rules on species protection.

\section{Toward a real or imaginary deadlock?}

Before proceeding with the detailed analysis of the current case law developments with respect to the EU nature directives, it is important to examine the application of the above-mentioned protection scheme on the ground. Although the EU nature directives are sometimes chastised for their excessive rigidity toward development, it is to be underlined that, in reality, only a few plans and projects have been cancelled on the basis of arguments explicitly linked to the EU nature directives (Morris 2011, Zijlmans and Woldendorp 2014). In spite of its relatively 
old age, the application and enforcement of the EU nature directives still leaves a lot to be desired. All in all, a limited number of plans and projects are subject to an appropriate assessment. An even smaller number of these assessments eventually lead to the application being refused. For example, in the UK, most major port developments have passed the tests of the Habitats Directive (Morris 2011). For the limited number of project developments that did not proceed in a Natura 2000 context, mostly poor compliance and economic complications were to blame (DEFRA 2012). In other member states, a similar picture emerges (Schoukens and Cliquet 2014). In general, poor compliance with the procedural and substantive requirements set out by Articles 6(3) and 6(4) of the Habitats Directive throughout spatial decision-making procedures, limited access to court in environmental cases, and fait accompli- scenarios are still seen as major obstacles to an effective application of the Habitats Directive on the ground in many member states (Milieu Ltd. et al. 2009).

Moreover, even when effectively applied in the existing planning procedures, the strict assessment rules set out by the EU nature directives are often treated as mere procedural formalities, with a relatively limited impact on the outcome of the decision-making process (Wandesforde-Smith and Watts 2014). Even the European Commission herself, when issuing opinions under the derogation clause of Article 6(4) for large infrastructure projects, does not always observe the strict derogation conditions. In some cases, economic factors are still superseding a strict assessment of the purported compensatory measures (Krämer 2009, McGillivray 2012).

However, in the wake of recent strict rulings of the EU judges on the Habitats Directive, a shifting attitude toward the enforcement of the EU nature directives can be detected at the national level (Schoukens and Bastmeijer 2015). Although at first, national courts proved to be quite reluctant to scrutinize planning decisions in the light of the procedural and substantive requirements set forth by the EU nature directives, recent case law developments showcase a greater willingness to apply a rigid standard of review in this respect (Zijlmans and Woldendorp 2014). Judges are now prepared to stop projects whenever an inadequate assessment has been carried out or an incorrect application of the rules on strict species protection has taken place (Verschuuren 2010, Schoukens and Cliquet 2014).

Throughout the past decades, extension of port areas (Morris 2011), the creation of new industrial estates, or the construction of major infrastructure works, including renewable energy projects (Jackson 2011, Frins and Schoukens 2014), increasingly collided with the conservation of Natura 2000 sites and the strict protection rules for endangered species, such as wild hamsters and natterjack toads (Verschuuren 2003). As a result of that, in some member states the EU protection rules are increasingly tagged as a burdensome obstacle course for project development (Jones QC 2012, Wandesforde-Smith and Watts 2014).

Although the application of Article 6(4) creates additional flexibility for project developments facing a negative ecological assessment, the derogation clause is not deemed a workable option for many private-based developments. According to the recent jurisprudence of the ECJ, private activities, such as cattle farming or the extension of a local undertaking are generally not eligible as "imperative reasons of overriding public interest" (ECJ 2012). Hence the clause cannot be used as a generic means to reconcile unfettered private development with conservation objectives.

However, also for large infrastructure projects, such as port extension works, the derogation clause is used only limitedly, because of the restrictive conditions to be met and the additional costs and delays associated thereto (Verschuuren 2010, Zijlmans and Woldendorp 2014). This probably helps to explain the rather modest application of the derogation clause so far. According to the figures of the European Commission, in the years 2004-2006 only 42 cases were reported from the 25 member states, with a majority of these taking place in Portugal and Germany (EC 2008, Krämer 2015).

\section{THE RISE OF RESTORATION ACTIONS AS MITIGATION UNDER THE EUROPEAN UNION NATURE DIRECTIVES}

\section{Mitigation and compensation under the European Union nature directives}

Faced with the incremental scrutiny at the planning and permit levels, mitigation and compensatory measures have become exceedingly popular tools for facilitating economic development in the vicinity of EU protected sites (Verschuuren 2010, Zijlmans and Woldendorp 2014). However, although Articles 6(3) and (4) of the Habitats Directive must be seen as a translation of the mitigation hierarchy, the EU nature directives do not contain an explicit reference to mitigation measures and only succinctly mention the term "compensatory measure" (McGillivray 2011). Nor do they explicitly lay down clear-cut rules in relation to biodiversity offsetting. It thus remains uncertain to what extent and under what specific conditions the EU nature directives offer sufficient discretion to the national or regional permit issuing instances for allowing a more flexible approach to mitigation within the context of the strict assessment procedures.

In particular, it was unsettled as to what extent restoration activities, aimed at restoration of degraded habitat or the creation of new habitats in the project area itself or its immediate vicinity, could be taken into consideration as generic mitigation in the context of an ecological assessment for a development project or, alternatively, to be treated as a genuine compensation effort when applying the strict derogation clause. The European Commission has laid down some general guidelines in this regard in its nonlegally binding guidance documents on Article 6 of the Habitats Directive (EC 2000, 2001, 2007/2012). The European Commission noted, for instance, that mitigation measures "are aimed at minimizing or even cancelling the negative impact of a plan or project, during or after its completion" (EC 2000:38). It added that "mitigation measures are an integral part of the specifications of a plan or project," whereas compensatory measures, which can only be considered under Article 6(4), are independent of the project and aim to offset the negative effects of the plan or project so that the overall coherence of the Natura 2000 network is maintained (EC 2007/2012). These compensatory measures are often labeled offsets in the available scientific literature, whereas on-site rehabilitation or restoration actions are deemed to precede the last stage of the so-called mitigation hierarchy (e.g., ten Kate and Crowe 2014). 
In other words, although mitigation measures are always on-site and functionally linked to the affected site, compensation, at least within the context of the EU nature directives, aims to generate additional environmental gains on other locations, but not necessarily in a different Natura 2000 site. However, it remained unclear to what extent on-site restoration efforts, that offset damage in the immediate vicinity of the affected nature, could still be integrated in project designs as mitigation.

In the framework of the recent BBOP standards of biodiversity offsets, such on site-restoration actions would not be considered as offsets, because they could be counted as measures aimed at reducing the project's residual impact, prior to the actual offsetting (BBOP 2012). However, within the context of the more flexible permitting strategies under the EU nature directives, no additional offsets are to be considered by the developer because the project is expected to not adversely affect the protected habitats with its on-site restoration actions. To make matters even more complicated, the European Commission stated in its 2007 Guidance on Strict Species Protection that mitigation measures could involve among others, "enlarging the site or creating new habitats in, or in direct functional relation to, a breeding site or resting place, as a counterweight to the potential loss of parts or functions of the site" (EC 2007:47). Hence a broader understanding of mitigation, also including on-site restoration measures, which do not necessarily avoid or prevent the environmental damage to materialize in the first place, did not seem completely off course within the context of the EU nature directives.

\section{Restoration measures as mitigation to better reconcile economic developments with biodiversity protection}

The quest for a more progressive understanding of mitigation under the umbrella of EU nature conservation law is understandable, at least when approached from a developer's point of view. Traditional avoidance measures, such as the relocation of a road trajectory, often do not suffice to reconcile development with the EU nature protection rules (Zijlmans and Woldendorp 2014). To facilitate development prone to interfere with EU protected sites and/or species, novel mitigation strategies are being relied upon in member states, such as in the Dutch spatial planning practices. Fearful of the administrative hurdles and delays associated with the application of the derogation clause, project developers and authorities were found increasingly ready to proactively integrate economic, social, and nature conservation objectives in one project to obtain more leverage at the permit level. Under this approach, habitat creation and restoration measures are integrated into the project designs for economic development. Such restoration measures generally include intentional activities that accelerate the recovery of degraded, damaged, or destroyed ecosystems, such as wetlands or pastures (Hobbs and Harris 2001, Allison 2004). In some instances, habitat creation measures are also envisaged, on sites devoid of any vegetation or natural assets. Under this view, on-site habitat restoration and/or creation measures that are within the project's footprint would still be eligible as mitigation. Any restorative actions beyond the direct scope of the project would be regarded as compensation.

Accordingly, it is assumed when granting permits for potentially harmful activities, that due regard should also be given to the positive effects that are expected to be generated by these on-site restoration actions and thus more leeway becomes available (Zijlmans and Woldendorp 2014). It is often submitted that, on a net base, the project would not adversely affect the protected nature. The negative effects are to be outbalanced by the oftenambitious restoration programs tied to the purported project developments. A useful side effect thereof is that, when taking into account ambitious restoration programs tied to project developments, less importance is to be given to the current unfavorable conservation status of a site, which often constitutes an important impediment for flexible permitting strategies.

The above-presented approaches have in common that they are built on the premise that some development is inevitable and that restoration actions can lead to real conservation outcomes at the landscape scale. The goal of the on-site actions can be seen as minimizing or counterbalancing residual impacts so as to consider them insignificant, and therefore not have to consider genuine offsets through Articles 6(4) and/or 16(1) of the Habitats Directive. Rather than sticking to the strict preventative rationale of the law, which would lead to more permit refusals for harmful developments, a more generous approach to mitigation would lead to win-win scenarios on the ground, both for biodiversity conservation and the business sector. Ideally, it would lead to fewer restrictions on economic activities, a reduced time to permit, and wider societal acceptance of economic development given the robust restoration programs linked thereto. Likewise, it is argued that the innovative approach might provide the much needed private sector boost to cash-strapped conservation finance. By granting developers more room to rely on the positive effects tied to restoration actions under the EU nature directives, the benefits of the socioeconomic developments can partly be used to finance conservation and restoration measures (Verschuuren 2010). Project developers are no longer obliged to take their permit application through the restrictive derogation procedures to see their project authorized under the Habitats Directive.

One of the most notable applications of this more progressive approach to mitigation took place in the context of the development of the Markermeer-IJmeer shallow-lake ecosystem in the Netherlands, a project that combines housing, recreation, water surplus storage, and nature conservation. The project entailed the construction of some 60,000 houses on islands, which would encroach upon several mussel beds serving as a foraging site for different protected bird species of a neighboring Natura 2000 site. However, to offset this damage, the project design had incorporated the creation of 132 hectares of new mussel beds, aimed at guaranteeing the conservation of the affected birds. As a result, the development, notwithstanding the fact that it would entail the outright destruction of breeding grounds, was granted a planning permit under Article 6(3) of the Habitats Directive (Zijlmans and Woldendorp 2014). Interestingly, the EC seemed to concur with the latter mitigation strategies, as long as it was provided that the project, as a whole, be subjected to a full-fledged appropriate assessment (Verschuuren 2010). A similar trend took hold within the Dutch permitting policies for projects interfering with strictly protected species, in which the creation of new nests and roosting grounds was used to avert the application of the strict derogation clauses for project developments that would lead to the destruction of nests or breeding sites of protected species (Fieten and Drahmann 2010). 
The more generous approach to mitigation in the context of an appropriate assessment has also grown increasingly popular among project developers in countries such as the UK. Reference can be made to a permit application for a major port development at Dibden (UK) in 2004. To avoid application of the derogation clause contained by Article 6(4), the project proposal included robust habitat creation measures outside the affected sites (McGillivray 2011). On-site or project-linked restoration actions are also increasingly popular as a mitigation tool in Belgium (Flemish region). For instance, in 2011, the Flemish government issued a planning permit for the construction of a road bypass in the province of Limburg (Noordzuidverbinding), which would cut through a Natura 2000 site. Because the creation of a nature corridor zone, aimed at offsetting the encroachment of the nearby Natura 2000 sites, had been included in the project design, the project was eventually authorized without the need to apply the derogation clause of Article 6(4) of the Habitats Directive (Schoukens and Cliquet 2014). The Flemish government also authorized a 1000 hectares extension of the Port of Antwerp in 2012 by taking into consideration the positive effects of a massive nature development plan linked to the harbor extension, aimed at the restoration of the to-be-affected Natura 2000 sites (Schoukens and Woldendorp 2014). Also, the partial destruction of a Natura 2000 site caused by port extension works was deemed acceptable in light of the site's natural integrity because of the creation of new robust nature in its immediate vicinity.

\section{THE BRIELS RULING OF THE EUROPEAN COURT OF JUSTICE AS A DECISIVE TURNING POINT?}

\section{Conflicting views at the national level}

In the absence of any conclusive regulatory definitions of "mitigation" and "compensation" under EU nature conservation law, it was no surprise to note a persistent conflation of the terms at the permit level (McGillivray 2011). The lack of a clear delimitation between mitigation and compensation is certainly not unique to the EU. In the United States, where mitigation and offsetting schemes have been present for decades, the term was misused to refer to activities designed to compensate for unavoidable environmental damage (ten Kate et al. 2004, Verschuuren 2003, 2010). Even the International Primer on Ecological Restoration of the Society of Ecological Restoration defines mitigation as "an action that is intended to compensate environmental damage" (SER 2004:12). That said, restoration actions used under the assessment stage of Article 6(3) and those based in the context of the derogation clause of Article 6(4), are to be distinguished as a matter of law. As alluded to, the former merely include on-site restoration measures or actions, whereas the latter can also encompass off-site measures (EC 2000, 2007/2012). Still, on the ground these restoration measures are almost identical, whatever the motive (Verschuuren 2010, Morris 2011, Quétier et al. 2014), which partly helps to explain why many business people advocated courts and judges to legalize the use of on-site restoration actions as a generic mitigation tool under the EU nature directives.

The Dutch administrative courts were among the first to pronounce themselves on the compatibility of the novel restorative strategies with the EU nature conservation law. In the above-portrayed case, the Dutch administrative court qualified the creation of new mussel beds as mitigation that could be taken into account in the assessment for the construction of the housing zone in the IJmeer given its functional linkage with the development (DCoS 2010). Likewise, the Dutch judges were also ready to qualify the creation of 22 hectares of foraging and resting area as a mitigation measure in the context of an assessment under Article 6(3) of the Habitats Directive (DCoS 2012a). In yet another landmark-ruling concerning the extension of the Port of Eemshaven, the Dutch administrative court held that the envisaged restoration measures, which included the removal of nitrogen by stripping off the upper layer of the soil, would render the nitrogen-sensitive habitats in the site more resilient and thus capable of absorbing the additional nitrogen deposition without any risk for further deterioration (DCoS 2014a).

In other instances, the more liberal reading of the EU nature directives was met with greater reluctance. In the context of the strict protection rules for Annex IV-species, for instance, the Dutch judges opted for a stricter stance and steadfastly rejected the use of restoration and rehabilitation actions as a means to bypass the need to apply for a derogation for harmful projects under Article 16(1) of the Habitats Directive (DCoS 2012b). A similar stringency could be detected in other member states. For instance, the Secretary of State of the UK refused permission for the port development at Dibden Bay because the habitat creation measures had been wrongly mischaracterized as mitigation by the port developer in the permit application (McGillivray 2011). However, given that in the Dibden Bay case, no functional link was present between the restoration measures and the project site, this outcome is not surprising as such. In turn, the Belgian administrative court held that the creation of the corridor zone in the context of the above-presented road bypass project should be labeled as a compensatory measure, which can only be taken into account whenever application had been made of the derogation clause of Article 6(4) of the Habitats Directive (BCoS 2013a). Also, eventually, the integral planning scheme for the extension of the Port of Antwerp was rejected by the Belgian judges because it was deemed incompatible with the strict precautionary approach set out by the EU nature directives and still envisaged the destruction of large tracts of protected habitats (BCoS 2013b, 2015).

\section{The Briels ruling of the European Court of Justice (ECJ)}

The question thus remained whether the ECJ, which has the ultimate power to provide authoritative interpretations of EU law, would confirm the legality of the innovative mitigation strategies in cases of habitat destruction by economic development. In the Briels case, the Dutch Council of State decided to question the ECJ about the leverage left for permit issuing instances to use restoration actions in the context of project developments.

This case revolved around the planning permission to the extension of the A2 motorway and the use of habitat creation measures as a counterbalance for the damage that would be inflicted upon the nitrogen-sensitive Molinia meadows, listed as protected habitat in Annex I to the Habitats Directive (Zijlmans and Woldendorp 2014). In particular, the ECJ was asked to indicate to what extent measures with a view to ensuring the creation of new meadows elsewhere in the same Natura 2000 site, to replace or augment the habitats affected by the increase of nitrogen deposition, could qualify as mitigation and thus be taken into account in the assessment for the purported project. 
The ECJ decided to dismiss the more liberal approach to mitigation in its ruling of 15 May 2014 (ECJ 2014). It grounded its reasoning on three premises. First, although accepting that measures, which form part of a plan or project and which effectively minimize its impacts may be taken into account under Article 6(3), the ECJ refused to qualify the creation of new meadows as mitigation measures because they do not lead to an adequate reduction of the said pollution. Instead it reasoned that such measures basically seek to counterbalance the unavoidable negative impacts that go along with the project and therefore should be tagged as compensatory measures within the meaning of Article 6(4). Second, with reference to the precautionary principle, the ECJ noted that any positive effect of a future creation of a new habitat that is aimed at compensating for the loss of area and quality of that same habitat type on a protected site, even if the new area will be bigger and of higher quality, is highly difficult to forecast with a degree of certainty and, in any event, will be visible only several years into the future. Third, the ECJ underlined that the restoration and enhancement measures, if inextricably linked to the road development project, could still be taken into account as compensation in the context of the derogation clause contained in Article 6(4). The fact that the measures envisaged are to be implemented in the same Natura 2000 site has no bearing on them being principally eligible as a compensatory measure.

\section{Wider relevance}

The Briels ruling is considered to be a landmark decision in the field of EU environmental law, especially given its major impact on national spatial planning practices throughout the EU. It represents the first legal decision in which the EU judges have made the effort to clarify the limits to be observed when using restoration actions within the context of the EU nature directives. By refuting the more flexible Dutch stance on mitigation, they reasserted the importance of the precautionary principle when issuing permits for harmful project development that might impact nearby Natura 2000 sites. As a matter of principle, the creation or restoration of habitats, even when located in the same Natura 2000 site and functionally linked to the project development, cannot serve as mitigation for the impairment of protected patches of protected habitats of the same type.

Although one might question whether the said restoration measures in the Briels case were really on-site, they were located in the same Natura 2000 site but apparently not in the immediate vicinity of the project site, the implications of the Briels' ruling appear rather straightforward: habitat restoration or creation actions can no longer be presented as mitigation whenever they do not reduce or avoid the expected environmental damage in the first place. Generally speaking, habitat restoration actions, even when they are located in the same Natura 2000 site or at the project site, can therefore no longer be used as a generic means to bypass the strict substantive and procedural rules contained by the EU nature directives in a context of outright habitat destruction or degradation.

Subsequently, this view has also been confirmed by more recent case law at the national level, in which restoration efforts can no longer be relied upon outside the context of the derogation clauses (DCoS 2015). However, permit issuing instances still enjoy some leeway to take into consideration restoration actions in the context of harmful project development. Pursuant to the ECJ's ruling, on-site restoration measures can obviously still serve as compensation when application is made of the derogation clause contained by Article 6(4). A similar view had already been upheld by the European Commission in its guidance documents (EC 2007/2012) and could be detected in earlier national practices in this respect (Schoukens and Cliquet 2014).

\section{CRITICAL REVIEW OF THE RECENT LEGAL DEVELOPMENTS}

In the light of the ongoing debate on the effectiveness of the EU nature directives, which recently has taken a new turn with its inclusion in the so-called Regulatory Fitness and Performance Programme (REFIT) by the European Commission (EC 2013), the outcome of the Briels ruling is not without importance. Taking into account the growing opposition to the allegedly overly stringent EU nature directives, there exists a clear risk that the Briels ruling might backfire on the EU's future biodiversity policy options.

The ruling could be used by the opponents of the EU nature directives as yet another poignant illustration of the alleged regulatory threat the protection rules pose on economic development within the context of Natura 2000. By radically excluding the use of restoration actions within the context of the habitats assessment under Article 6(3) in a context of habitat impairment, the EU judges apparently leave little room for additional flexibility.

Whereas biodiversity offsets and restoration actions are often presented as an instrument to help relieve tension between economic growth and conservation, the ECJ's ruling seems to limit the chances for the emergence of a more reconciliatory approach in the context of protected habitats and species. Critics could submit that the ECJ's approach might in practice significantly reduce the room for environmental gains. In spite of environmental objections, many harmful developments are deemed inevitable and thus will still be authorized by national authorities throughout the coming decades. Accordingly, the ECJ's strict stance could backfire for the preservation of EU's biodiversity by its steadfast refusal not to be more pragmatic visà-vis the application of the EU protection rules in the context of spatial and economic development in a Natura 2000 context.

To be more precise, the ECJ's ruling might lead to less funding for on-site restoration measures in the context of economic developments. Also, the applied rationale would probably not create more incentives for off-site restoration (offsets). In this respect, it needs to be reiterated that the restrictive derogation clauses, such as Article 6(4) of the Habitats Directive, are only accessible for projects of overriding public interest for which no less harmful alternatives exist and thus do not present a viable alternative for many projects. It is therefore very likely that the ECJ's ruling might effectively lead to more permit refusals, which would as such keep additional environmental damage from arising in the first place.

That being said, the ECJ could still be accused of having created an additional barrier to the inclusion of more robust restoration measures within project developments. The eventual outcome of the Briels case before the Dutch administrative court serves as a powerful warning in this regard. In the wake of the EU-ruling, a 
new assessment had been drafted for the projected road development works, which concluded that, contrary to earlier reports, the blue marshes were still at a favorable conservation status and thus no further extension of the protected habitats was deemed necessary (DCoS 2014b). Ironically, the more rigid approach to mitigation might eventually lead to more flawed ecological assessments, which increasingly downplay the impact of the project on protected biodiversity. Although there are no indications that the conclusions of the second assessment are incorrect, it is not excluded that the recent jurisprudence at the EU level can, rather perversely, lead to a sharp rise in the number of scientifically unsound ecological assessments under Article 6 (3). Indeed, project developers could be more inclined to bias the findings of the ecological assessments. For, whenever the assessment indicates that no adverse negative effects are to be expected, there will be no longer any need to implement restoration actions to avoid the application of the bothersome derogation procedure.

However, only a limited number of projects have been rejected on the basis of conservation-related arguments so far. Along those lines, it could be submitted that the focus on the limited effectiveness of the EU nature directives is misleading in itself, because it blames the EU nature directives for factors well beyond its control (poor compliance, the increasing human footprint, fragmentation, and climate change) and ignores the fact that there is a certain logic in accepting that unsustainable development projects can only be authorized whenever application is made of a restrictive derogation clause. It is therefore important to assess how the decision stands relative to some of the key challenges for achieving no net loss for the EU's most threatened species and habitats (Quétier et al. 2014, ten Kate and Pilgrim 2014).

Mitigation hierarchy: restoration actions as a last resort option? A first criterion to assess the viability of the ECJ's approach is the mitigation hierarchy, which proposes a sequence of avoiding, reducing, and offsetting or repairing impacts on the environment (ten Kate and Pilgrim 2014). Currently, it is widely accepted that restoration measures have to be applied within the context of the mitigation hierarchy. Although the ECJ did not explicitly refer to the mitigation hierarchy in its 2014 ruling, the ECJ clearly uses the mitigation hierarchy as an implicit reference criterion in its qualification of the habitat creation measures at stake in the Briels case.

The EU judges drew a clear distinction between mitigation measures, which aim to avoid or reduce the negative effects of a project, on the one hand, and compensation measures, which serve to counterbalance the residual negative effects of a project, on the other hand. Because the habitat creation measures at stake, even when located in the same Natura 2000 site, were neither aimed at avoiding nor reducing the significant negative effects linked to the development, they could not be qualified as avoidance nor mitigation measures under Article 6(3). The ECJ's stance appears reasonable and justified when approached from the perspective of the mitigation hierarchy. The ECJ's reasoning explicitly reflects the commonly accepted view that biodiversity offsets can only be used as a last resort, once prior steps in the mitigation hierarchy have maximized reduction of residual impact (Bull et al. 2013, Gardner et al. 2013, Quétier et al. 2014). Even if one distinguishes on-site restoration actions from actual offsets (e.g., ten Kate and Crowe 2014), which are mostly located outside the impact area, it is still unconvincing to qualify restoration actions as mitigation under Article 6(3) of the Habitats Directive. The reluctance of the ECJ vis-à-vis novel mitigation strategies under the generic decision-making procedures laid down by the Habitats Directive appears justified. The risk that such a flexible mitigation strategy would undercut the crucial prior steps in the mitigation hierarchy should not be underestimated (Clare et al. 2011).

A more liberal understanding of the mitigation requirements under the EU nature directives entails the risk that less importance will be given to the first important step in the mitigation hierarchy, avoidance. The increasing reliance on restoration measures in earlier stages of the decision-making process could create the impression that such actions amount to a "licence to trash" (Reid 2011, Quétier et al. 2014, ten Kate and Pilgrim 2014, Lapeyre et al. 2015), whereas the destruction of the EU's most valuable and threatened habitats should, as a matter of principle, be avoided from the very outset (van Teeffelen et al. 2014). It should only be allowed whenever the public interests related to the infrastructure project clearly outweigh the ecological importance of the preservation of the Natura 2000 site. This would effectively be ensured by applying the derogation clauses that are currently present in EU nature conservation law. Taking stock of the poor track record of many member states in relation to the application of the existing EU nature protection rules in the context of developments (Krämer 2015), legalizing more progressive mitigation strategies under the EU nature directives might thus eventually exacerbate the plight of the EU's most valuable natural sites. At the same time the ECJ also made it clear that its interpretation should not necessarily lead to a deadlock on the ground given the possibility to use the derogation clause for largescale infrastructure projects. This is not without importance. For, in contrast to the widely established view among member states that the derogation clauses contained by the Habitats Directive pose an insuperable obstacle for authorization, recent research revealed that, both at the national and EU-level, cases in which an application of the derogation clause is explicitly rejected, remain very rare (Clutten and Tafur 2012).

In fact, it is to be recalled that the existing derogation clause from Article 6(4) had been explicitly included in the EU nature directives to provide the member states with additional leverage in the context of project developments prone to adversely affect EU protected nature. For instance, over the past decade, several large-scale development projects, such as the extension of the Port of Antwerp (Belgium 2002), the Bothnia Railway project (Sweden 2003), TGV East (France 2004), and the port construction at Granadilla (Spain 2006) have been authorized through the derogation procedures (McGillivray 2012, Schoukens and Cliquet 2014). In addition, the European Commission, when asked to deliver an opinion on the acceptability of a request for the application of the derogation clause contained by Article 6(4), has only in one instance delivered a negative opinion (Sharpston 2013).

Arguably, not all of these derogation cases can be presented as faultless examples of sustainable development that are meeting the substantive requirements of the EU nature directives (McGillivray 2012). Although some of these projects included 
impressive robust restoration efforts on paper, sometimes encompassing more than 1000 hectares, others lacked operational offsets at the time of approval (Verschuuren 2010).

We do not advocate for a more lenient approach to the derogation clauses that are currently present within the EU nature directives. Their application should remain confined to cases in which other societal interests would still warrant the realization of the development project. However, the above-presented findings add nuance to the debate by poignantly illustrating that the mere perception of the derogation clauses as an insurmountable hurdle is not correct.

\section{Addressing failures: ensuring the effectiveness of restoration actions?}

The ECJ's reliance on the precautionary principle also appears sound in the light of the available scientific research on the effectiveness of habitat creation and/or restoration measures so far. Whereas the science for designing and implementing ecological restoration, rehabilitation, or conservation actions is still relatively young (Suding 2011, Quétier et al. 2014), recent studies on the practical effects of restoration measures consistently point to the relative ineffectiveness of restoration efforts in the context of biodiversity offsetting schemes (MorenoMateos et al. 2012, 2015), especially in relation to measures aimed at the recreation of habitats (Kozich and Halvorsen 2012).

For now, it is commonly understood that restoration efforts, when applied in the context of planning permit schemes, tend to have delayed and have led to very uncertain results, even for easy to restore habitats, such as wetlands and grasslands (Woodstock et al. 2010). All too often, current offset practices fail to take into account the uncertainty in restoration and its considerable time lags and therefore seldom reach ecological equivalence (Moilanen et al. 2009, Quétier and Lavorel 2011, Curran et al. 2014). Without explicitly referring to scientific studies pointing to the limited effectiveness of ecological restoration, the ECJ's reasoning clearly echoes the studies' findings.

By principally excluding the use of restoration actions within the context of the general assessment obligation laid down by Article $6(3)$, even when they are functionally linked to the purported project, the ECJ effectively implements the recommendations of many of the recent studies in this regard. Seeing that ecological research has consistently demonstrated that there are no quick fixes for threatened nature, especially not for old growth habitats, it appears more than reasonable to limit the leeway left for planning authorities under Article 6(3). One should bear in mind that the Natura 2000 network includes the EU's most threatened habitats. Therefore, opening the door for an unlimited use of offsets might not be the most desirable option to choose in the light of the current predicament of the EU's biodiversity (Pilgrim et al. 2013). Obviously, one could contend that the criticism pertaining to the limited effectiveness of restoration actions would be equally relevant for restoration actions that are implemented under the derogation clause of Article 6(4) of the Habitats Directive. In itself, the distinct legal qualification given to habitat creation or restoration measures has little bearing on their effectiveness on the ground. However, equating the derogation clause to the generic protection rules would undermine the preventative approach. As alluded to above, Article 6(4) is to be approached as a restrictive derogation clause, which can only be rendered applicable whenever the invoked social or economic interests clearly outweigh the importance tied to the preservation of the EU's protected habitats or species. Hence, it guarantees that offsetting or restoring never turns into a generic practice. In many instances, it is still better to prevent damage to valuable nature than issue permits allowing for further destruction.

Also, it still appears acceptable to incorporate restoration measures as mitigation in an assessment whenever it can be demonstrated that the measures will lead to more resilient habitats, capable of withstanding the future impairments linked to the purported development. Ostensibly, the likelihood of success will be determinative here. This route will probably not be a viable pathway for developments that imply an outright destruction of protected habitats.

However, in the specific context of projects entailing additional nitrogen deposits, such a strategy, whenever proactively implemented in the planning process, can create additional leverage. In that regard, it is important to note that restoring degraded ecosystems is expected to be more likely to succeed, and more rapidly, than recreating habitats (Moreno-Matteos et al. 2012, Quétier et al. 2014). Still, given the persisting doubts on the adequacy of habitat restoration measures to reduce atmospheric nitrogen deposition on terrestrial habitats (Stevens et al. 2013), demonstrating the effectiveness of the said measures will evidently remain crucial to align this approach with the substantive requirements of Articles 6(3) and (4) (Frins and Schoukens 2014).

\section{Additionality: mitigation and compensation actions that go beyond the existing obligations?}

In general, demonstrating the additionality of mitigation, restoration, or offsetting measures will be crucial to achieve a no net loss (Maron et al. 2013). Only biodiversity benefits that are additional to a baseline scenario or the existing commitments count as valid restoration or offset (Marron et al. 2015). Thus, by having put clear boundaries to the use of restoration actions within the context of Article 6(3), the ECJ can also be credited for having indirectly ensured the additionality of these measures in the context of EU nature conservation law.

In this respect, it is useful to underline that the Habitats Directive already contains the duty for the member states to consider habitat creation and/or restoration measures for degraded Natura 2000 sites (Article 6(1) Habitats Directive, EC 2014). Therefore, it remains crucial to establish a clear-cut baseline scenario against which the additionality of the mitigation and/or compensation measures can be measured (Maron et al. 2015). To avoid a net loss, it needs to be ensured that restoration actions that are used in the context of project designs go beyond the existing legal obligations (Gibbons et al. 2009).

In the Briels case, serious doubts had arisen in relation to the additionality of the habitat creation measures. According to the opponents of the motorway extension project, the creation of new areas of Molinia meadow had to be framed in the context of an existing conservation program (LIFE+). Advocate General Sharpston explicitly outlawed the possibility that management measures, which are required under Article 6(1), could serve at the same time as mitigating elements in part of the project (Sharpston 2014). In doing so, she aligned herself with the viewpoint of the European Commission, which had already 
underscored that restoration measures that are required for the normal implementation of the Habitats or Birds Directive cannot be considered compensatory for a damaging project (EC 2007/2012).

In its final ruling, however, the ECJ did not explicitly touch upon the additionality requirements. However, by setting out stringent conditions for the use of restoration actions under the EU nature directives, the EU judges warranted that existing restoration commitments are not to be "double booked" under Article 6(1) and under Articles 6(3) and (4) of the Habitats Directive.

When not backed up by more robust restoration efforts that go beyond the specific context of offsetting specific harmful interventions, it remains doubtful whether the EU's ambitious biodiversity targets will ever be met (Schoukens 2015). If member states are not poised to invest in large-scale autonomous restoration programs for degraded Natura 2000 sites in the coming years, the ongoing biodiversity crisis will probably not be reversed any time soon. Indeed, the most formidable obstacle for granting permits in a Natura 2000 context is often not, as such, the alleged strict protection rules but rather the fact that so many protected habitats and species are at an unfavorable conservation status throughout the EU (EEA 2015). In such context, every additional impact might be deemed significant under the existing protection rules, especially whenever taking into consideration cumulative effects, as is required under Article 6(3) of the Habitats Directive.

In other words, the more effective efforts that are put in the recovery of degraded Natura 2000 sites, the more margins there will be for planning authorities when issuing permits for new project developments under the EU nature directives. Along those lines, the ECJ's strict stance on the habitats assessment should be welcomed for having ensured that member states will eventually have to take their autonomous restoration duties more seriously and be obliged to ensure that development-led restoration actions go beyond what is required on the basis of existing nature conservation policies (Frins and Schoukens 2014).

\section{CONCLUSIONS AND OUTLOOK}

The EU nature directives have recently been facing serious opposition from business people but also, increasingly, from some member states that struggle with the exclusive focus on conservation objectives when issuing permits for harmful project developments. Although there is no concrete evidence that the Habitats Directive poses an insurmountable constraint to sustainable development, an increasing number of business people and politicians is of the opinion that the protection rules are too rigid and lead to disproportionate costs for the economy.

Against this deregulatory backdrop, the strict preventative rationale used by the ECJ in its Briels decision, could turn out to be an argument against the EU nature directives in their current form.

It has now has become clear from the Briels ruling that restoration actions cannot be used as mitigation in the context of the EU nature directives, unless it can be demonstrated that they directly mitigate or reduce the effects linked to the development on the targeted patches of habitats. Consequently, especially in member states where the national courts now insist on a strict application of the precautionary principle and most habitats and species find themselves already at an unfavorable conservation status, there is less room for leverage at the permit level (Frins and Schoukens 2014, Schoukens and Bastmeijer 2015). Still, in reality, there often is no real deadlock on the ground because most development projects still go ahead.

Our analysis has demonstrated that there are three main reasons why the ECJ's rather cautious approach to mitigation and restoration strategies under the EU nature directives is the correct one. First, in the light of the recently published studies on the limited effectiveness of ecological restoration efforts so far, the ECJ had every reason to reassert the preventative foundations upon which the habitats assessment obligation is grounded. Given the limited material scope of the EU nature directives, which only include the EU's most endangered habitats and species, opening up the protection rules to more generous forms of restoration or even offsetting would, in our view, not be the right answer in times of ever-continuing biodiversity decline. A reinforcement of the preventative approach, which assumes that some impact to biodiversity are nonoffsetable, given the unacceptable societal and ecological consequences they might entail, appears to be a better policy option to achieve the no net loss target. The Briels ruling of the ECJ could be tagged as a unmistakable hint toward the member states that, rather than weakening the existing protection rules for the most vulnerable habitats and species, the focus should be redirected toward the protection of the wider landscape and biodiversity in general, which are still often left unaddressed by the existing nature conservation laws (van Teeffelen et al. 2014, Schoukens 2015).

Second, as to the alleged inflexibility of the interpretation that has been given by the ECJ to the habitats assessment rules, the words of Sagoff in relation to the US Endangered Species Act (ESA) need to be recalled. In response to the growing criticism to the ESA he stated that: "To notice that the Endangered Species Act is not cost-beneficial is to recognize the obvious. That is the point of the Act, and of much of our environmental legislation" (Sagoff 1981:1418). The same can be said about the EU nature directives. Sufficiently strict environmental regulations remain vital in protecting nature and the wider environment. Opening the door for more flexible approaches might create more support for environmental regulations among business people and politicians. In the current context, it indeed remains unrealistic to advocate for a complete absence of economic development. Flexible permitting strategies are obviously capable of creating environmental benefits over a business-as-usual scenario (Moreno-Mateos et al. 2015). However, when overly relied upon, more flexibility is prone to lead to more unsound development and a mere continuation of the ongoing biodiversity decline. Averting manifest unsustainable development should remain a core target of any effective nature conservation law, especially because unfettered economic growth is currently singled out as one of the root causes of biodiversity loss on our planet (Lenzen et al. 2012, Mikkelson 2013). Furthermore, one should bear in mind that only because of the strict case law at the EU level, project developers are now willing to take into consideration the preventative approach underpinning the EU nature directives in the first place. Thus, the strict EU nature protection rules should be credited for urging the member states to take their generic restoration commitments more seriously instead of being portrayed as a burdensome obstacle course. The rationale of the 
EU judges pushes the member states to establish clear baseline scenarios. It should not be forgotten that eventually, with more restored and resilient protected areas, less deadlock scenarios would unfold on the ground in the first place (Frins and Schoukens 2014).

Third, we also have established that not all margins to maneuvre are lost at the permit level. Not only is it still possible to rely on the beneficial effects of genuine avoidance measures within the context of an assessment, but the derogation clauses can still be applied for large infrastructure projects. Even more so, it has been suggested that, in some instances, a more coordinated and proactive application of restoration in the context of project development could constitute a more promising pathway to a more sustainable project development that fits in with the requirements of EU nature conservation law. Indeed, whereas the many uncertainties related to ecological restoration are prone to further compromise the effectiveness thereof, a more generic strategy, which incorporates adaptive management techniques in an early planning stage, might overcome the regulatory challenges in this regard (Maron et al. 2012). A strong incorporation of adaptive management at permit or planning level, backed up by strict revision clauses, can help to resolve uncertainties in achieving restoration targets for at least some project developments (Opdam et al. 2009, Frins and Schoukens 2014).

In conclusion, our analysis has indicated that the Briels ruling of the ECJ stands out as a prime example of sensible environmentalism in the courtroom. However, given that the EU judges have proven willing to show their commitment to safeguarding the effectiveness of the EU nature directives, it still remains to be seen whether project developers and planning authorities are willing to take up the challenge. Our main concern is that the messages arising out of the recent rulings at the EU level will be disregarded in a quest for more flexibility and deregulation. We hope that our work will urge developers, regulators, environmental NGOs, and scientists to thoroughly and openly discuss the opportunities and drawbacks associated with implementing more progressive mitigation strategies in the context of the existing EU nature directives.

Responses to this article can be read online at: http://www.ecologyandsociety.org/issues/responses. $\mathrm{php} / 8456$

\section{LITERATURE CITED}

Allison, S. K. 2004. Perspective: what do we mean when we talk about ecological restoration? Ecological Restoration 22:281-286. http://dx.doi.org/10.3368/er.22.4.281

Belgian Council of State (BCoS). 2013a. Case no. 223.083 Vzw Natuurpunt Limburg. Belgian Council of State, Brussels, Belgium.

Belgian Council of State (BCoS). 2013b. Case no. 225.676 Hilde Orleans. Belgian Council of State, Brussels, Belgium.

Bull, J. W., K. B. Shuttle, A. Gordon, N. J. Singh, and E. J. MilnerGulland. 2013. Biodiversity offsets in theory and practice. Oryx 47(3):369-380. http://dx.doi.org/10.1017/s003060531200172x
Borgström, S., and F. H. Kistenkas. 2014. The compatibility of the habitats directive with the novel EU green infrastructure policy. European Energy and Environmental Law Review 23:36-44.

Business and Biodiversity Offsets Programme (BBOP). 2012. Standards on biodiversity offsets. Business and Biodiversity Offsets Programme, Washington, D.C., USA. [online] URL: http://bbop.forest-trends.org/pages/guidelines

Calvet, C., O. Guillaume, and N. Claude. 2015. Tracking the origins and development of biodiversity offsetting in academic research and its implications for conservation; a review. Biological Conservation 192:492-503. http://dx.doi.org/10.1016/j.biocon.2015.08.036

Chapron, G., P. Kaczensky, J. D. C. Linnell, M. von Arx, D. Huber, H. Andrén, J. V. López-Bao, M. Adamec, F. Álvares, O. Anders, L. Balčiauskas, V. Balys, P. Bedő, F. Bego, J. C. Blanco, U. Breitenmoser, H. Brøseth, L. Bufka, R. Bunikyte, P. Ciucci, A. Dutsov, T. Engleder, C. Fuxjäger, C. Groff, K. Holmala, B. Hoxha, Y. Iliopoulos, O. Ionescu, J. Jeremiã, K. Jerina, G. Kluth, F. Knauer, I. Kojola, I. Kos, M. Krofel, J. Kubala, S. Kunovac, J. Kusak, M. Kutal, O. Liberg, A. Majić, P. Männil, R. Manz, E. Marboutin, F. Marucco, D. Melovski, K. Mersini, Y. Mertzanis, R. W. Mysłajek, S. Nowak, J. Odden, J. Ozolins, G. Palomero, M. Paunović, J. Persson, H. Potočnik, P.-Y. Quenette, G. Rauer, I. Reinhardt, R. Rigg, A. Ryser, V. Salvatori, T. Skrbinšek, A. Stojanov, J. E. Swenson, L. Szemeth, A. Trajçe, E. TsingarskaSedefcheva, M. Váňa, R. Veeroja, P. Wabakken, M. Wölfl, S. Wölfl, F. Zimmermann, D. Zlatanova, and L. Boitani. 2014. Recovery of large carnivores in Europe's modern humandominated landscapes. Science 346:1517-1519. http://dx.doi. org/10.1126/science. 1257553

Clare, S., N. Krogman, L. Foote, and N. Lemphers. 2011. Where is the avoidance in the implementation of wetland law and policy? Wetland Ecology and Management 19:165-182. http://dx.doi. org/10.1007/s11273-011-9209-3

Cliquet, A., C. W. Backes, J. Harris, and P. Howsam. 2009. Adaptation to climate change: legal challenges for protected areas. Utrecht Law Review 5:158-175. http://dx.doi.org/10.18352/ $\underline{\text { ulr. } 100}$

Clutten, R., and I. Tafur. 2012. Are imperative reasons imperiling the habitats directive? An assessment of article 6(4) and the IROPI exception. Pages 167-182 in G. Jones QC, editor. The habitats directive - a developer's obstacle course? Hart, Oxford, UK.

Curran, M., S. Hellweg, and J. Beck. 2014. Is there any empirical support for biodiversity offset policy? Ecological Applications 24:617-632. http://dx.doi.org/10.1890/13-0243.1

Donald, P. F., F. J. Sanderson, I. J. Burfield, S. M. Bierman, R. D. Gregory, and Z. Waliczky. 2007. International conservation policy delivers benefits for birds in Europe. Science 317 (5839):810-813. http://dx.doi.org/10.1126/science.1146002

Dutch Council of State (DCoS). 2010. Case no. 200902644/1/R2 Stichting Stichting Verantwoord Beheer IJsselmeer. Dutch Council of State, The Hague, The Netherlands.

Dutch Council of State (DCoS). 2012a. Case no. 201100875/1/R2 $X$. Dutch Council of State, The Hague, The Netherlands.

Dutch Council of State (DCoS). 2012b. Case no. 201104545/T/ T1/A3 Stichting Stichting Baanstee Noord, NEE! Dutch Council of State, The Hague, The Netherlands. 
Dutch Council of State (DCoS). 2014a. Case no. 201304768/1/R2 Vereniging naar Duits recht Landesverband Burgerinitiativen Umweltschutz Niedersachsen e.V. Dutch Council of State, The Hague, The Netherlands.

Dutch Council of State (DCoS). 2014b. Case no. 201110075/4 and $201201853 / 3 X$. Dutch Council of State, The Hague, The Netherlands.

Dutch Council of State (DCoS). 2015. Case no. 201401736/5/R1, Vereniging voor Natuurstudie en bescherming IJsseldelta. Dutch Council of State, The Hague, The Netherlands.

European Commission (EC). 1992. Directive 92/43/EEC of 21 May 1992 on the conservation of natural habitats and wild fauna andflora. [online] URL: http://ec.europa.eu/environment/nature/ legislation/habitatsdirective/index en.htm

European Commission (EC). 2000. Managing Natura 2000-sites: the provisions of article 6 of the 'habitats' directive 92/43/EEC. European Communities, Luxembourg City, Luxembourg. http:// ec.europa.eu/environment/nature/natura2000/management/docs/ art6/provision of art6 en.pdf

European Commission (EC). 2001. Assessment of plans and projects significantly affecting Natura 2000-site. Methodological guidance on the provisions of article 6(3) and (4) of the babitats directive 92/43/EEC. European Communities, Luxembourg City, Luxembourg. [online] URL: http://ec.europa.eu/environment/ nature/natura2000/management/docs/art6/natura_2000_assess_en. pdf

European Commission (EC). 2007. Guidance document on the strict protection of animal species of community interest under the habitats directive 92/43/EEC. European Communities, Luxembourg City, Luxembourg. [online] URL: http://ec.europa.eu/environment/ nature/conservation/species/guidance/pdf/guidance en.pdf

European Commission (EC). 2007/2012. Guidance document on article 6(4) of the 'habitats directive' 92/43/EEC. European Communities, Luxembourg City, Luxembourg. [online] URL: http://ec.europa.eu/environment/nature/natura2000/management/ docs/art6/new guidance art6 4 en.pdf

European Commission (EC). 2008. Implementation of Article 6 (4) first paragraph, of council directive 92/43/EEC during the period 2004-2006. Summary report. European Communities, Luxembourg City, Luxembourg. [online] URL: http://ec.europa. eu/environment/nature/knowledge/rep habitats/docs/art 6 4.pdf

European Commission (EC). 2011. Communication from the Commission to the European Parliament, the Council, the Economic and Social Committee and the Committee of the Regions: our life insurance, our natural capital: an EU biodiversity strategy to $2020(\operatorname{COM}(2011) 244$ final, 2011). European Communities, Luxembourg City, Luxembourg. [online] URL: http://eur-lex.europa.eu/legal-content/EN/TXT/ $\underline{\mathrm{PDF} / \text { ?uri=CELEX:52011DC0244\&from }=\mathrm{EN}}$

European Commission (EC). 2013. Communication from the Commission to the European Parliament, the Council, the European Economic and Social Committee and the Committee of the Regions. Regulatory fitness and performance (REFIT): results and next steps. European Communities, Luxembourg City, Luxembourg. [online] URL: http://eur-lex.europa.eu/resource.html?uri=
cellar:97b27b3a-2ceb-11e3-8d1c-01aa75ed71a1.0002.01/DOC_1\&format= PDF

European Commission (EC). 2014. Establishing conservation measures for Natura 2000 sites. European Communities, Luxembourg City, Luxembourg. [online] URL: http://ec.europa. eu/environment/nature/natura2000/management/docs/conservation $\%$ 20measures.pdf

European Court of Justice (ECJ). 2004. Case C-127/02 Landelijke Vereniging tot Behoud van de Waddenzee en Nederlandse Vereniging tot Bescherming van Vogels $v$ Staatssecretaris van Landbouw, Natuurbeheer en Visserij ECR I-7405. European Court of Justice, Luxembourg City, Luxembourg. [online] URL: $\underline{\text { http:// }}$ eur-lex.europa.eu/legal-content/EN/TXT/HTML/?uri= CELEX:62002CJ0127\&from $=E N$

European Court of Justice (ECJ). 2005. Case C-441/03 Commission v. The Netherlands. ECR I-3043. European Court of Justice, Luxembourg City, Luxembourg.[online] URL: http:// curia.europa.eu/juris/document/document.jsf?docid=49913\&doclang= EN

European Court of Justice (ECJ). 2014. Case C-521/12 Briels and Others v. Minister van Infrastructuur en Milieu. Court of Justice of the European Union, Luxembourg City, Luxembourg. [online] URL: http://curia.europa.eu/juris/liste.jsf?num=C-521/12

European Environment Agency (EEA). 2015. SOER 2015 - the European environment - state and outlook 2015. European Environment Agency, Copenhagen, Denmark. [online] URL: http://www.eea.europa.eu/soer

European Parliament and Council of the European Union. 2004. Directive 2004/35/CE of the European Parliament and of the Council of 21 April 2004 on environmental liability with regard to the prevention and remedying of environmental damage. European Commission, Brussels, Belgium. [online] URL: http://eur-lex. europa.eu/legal-content/EN/TXT/HTML/?uri=CELEX:32004L$\underline{0035 \& \text { from }=\mathrm{EN}}$

European Parliament and Council of the European Union. 2009. Directive 2009/147/EC of the European Parliament and of the Council of 30 November 2009 on the conservation of wild birds. European Commission, Brussels, Belgium. [online] URL: $\underline{\text { http:// }}$ ec.europa.eu/environment/nature/legislation/birdsdirective/index en. $\underline{\mathrm{htm}}$

European Parliament and Council of the European Union. 2011. Directive 2011/92/EU of the European Parliament and of the Council of 13 December 2011 on the assessment of the effects of certain public and private projects on the environment. European Commission, Brussels, Belgium. [online] URL: http://eur-lex. europa.eu/legal-content/EN/TXT/?uri=CELEX:32011L0092

Fieten, R., and A. Drahmann. 2010. Nieuw beoordelingskader voor Ffw-ontheffingen: probleem opgelost? Bouwrecht 181-186.

Frins, R., and H. Schoukens. 2014. Balancing wind energy and nature protection: from policy conflicts towards genuine sustainable development. Pages 84-110 in L. Squitani, B. Vanheusen, B. Vanheusden, and M. Reese, editors. Sustainable energy united in diversity - challenges and approaches in energy transition in the European Union. Europa Law, Groningen, The Netherlands. 
Froger, G., S. Ménard, and P. Méral. 2015. Towards a comparative and critical analysis of biodiversity banks. Ecosystem Services 15:152161. http://dx.doi.org/10.1016/j.ecoser.2014.11.018

Gardner, T. A., A. Von Hase, S. Brownlie, J. M. M. Ekstrom, J. D. Pilgrim, C. E. Savy, R. T. T. Stephens, J. Treweek, G. T. Usscher, G. Ward, and K. ten Kate. 2013. Biodiversity offsets and the challenge of achieving no net loss. Conservation Biology 27 (6):1254-1264. http://dx.doi.org/10.1111/cobi.12118

Gibbons, P., S. V. Briggs, D. Ayers, J. Seddon, S. Doyle, P. Cosier, C. McElhinny, V. Pelly, and K. Roberts. 2009. An operational method to assess impacts of land clearing on terrestrial biodiversity. Ecological Indicators 9:26-40. http://dx.doi. org/10.1016/j.ecolind.2008.01.006

Hobbs, R. J., and J. A. Harris. 2001. Restoration ecology: repairing the Earth's ecosystems in the new millennium. Restoration Ecology 9:239-246. http://dx.doi.org/10.1046/ j.1526-100x.2001.009002239.x

Hough, P., and M. Robertson. 2009. Mitigation under section 404 of the clean water act: where it comes from, what it means. Wetlands Ecology and Management 17(1):15-33. http://dx.doi. org/10.1007/s11273-008-9093-7

Jackson, A. L. R. 2011. Renewable energy vs. biodiversity: policy conflicts and the future of nature conservation. Global Environmental Change 21:1195-1208. http://dx.doi.org/10.1016/j. gloenvcha.2011.07.001

Jones QC, G. 2012. The habitats directive: a developer's obstacle course? Hart, Oxford, UK.

Kistenkas, F. H. 2013. Rethinking European nature conservation legislation: towards sustainable development. Journal for European and Planning Law 10(1):72-84. http://dx.doi. org/10.1163/18760104-01001005

Kozich, A. T., and K. E. Halvorsen. 2012. Compliance with wetland mitigation standards in the Upper Peninsula of Michigan, USA. Environmental Management 50:97-105. http:// dx.doi.org/10.1007/s00267-012-9861-2

Krämer, L. 2009. The European Commission's opinions under article 6 (4) of the Habitats Directive. Journal of Environmental Law 21:59-85. http://dx.doi.org/10.1093/jel/eqn028

Krämer, L. 2015. Implementation and enforcement of the Habitats Directive. Pages 229-244 in C.-H. Born, A. Cliquet, H. Schoukens, D. Misonne, and G. Van Hoorick, editors. The Habitats Directive in its EU environmental law context: European nature's best hope? Routledge, Oxford, UK.

Lapeyre, R., G. Froger, and M. Hrabanski. 2015. Biodiversity offsets as market-based instruments for ecosystem services? From discourse to practices. Ecosystem Services 15:125-133. http://dx. doi.org/10.1016/j.ecoser.2014.10.010

Lenzen, M., D. Moran, K. Kanemoto, B. Foran, L. Lobefaro, and A. Geschke. 2012. International trade drives biodiversity threats in developing nations. Nature 489:109-112. http://dx.doi. org/10.1038/nature11145 http://dx.doi.org/10.1016/j.biocon.2015.05.017

López-Bao, J. V., J. C. Blanco, A. Rodriguez, R. Godinho, V. Sazatornil, F. Alvares, E. J. Garcia, L. Llaneza, M. Rico, Y. Cortés, V. Palacios, and G. Chapron. 2015. Toothless wildlife protection laws. Biodiversity and Conservation 24(8):2105-2108. http://dx. doi.org/10.1007/s10531-015-0914-8

Maron, M., A. Gordon, B. G. Mackey, H. P. Possingham, and J. E. M. Watson. 2015. Conservation: stop misuse of biodiversity offsets. Nature 523:401-403. http://dx.doi.org/10.1038/523401a

Maron, M., R. J. Hobbs, A. Moilanen, J. W. Matthews, K. Christie, T. A. Gardner, D. A. Keith, D. B. Lindenmayer, and C. A. McAlpine. 2012. Faustian bargains? Restoration realities in the context of biodiversity offset policies. Biodiversity Conservation 155:141-148. http://dx.doi.org/10.1016/j.biocon.2012.06.003

Maron, M., J. R. Rhodes, and P. Gibbons. 2013. Calculating the benefit of conservation actions. Conservation Letters 6 (5):359-367. http://dx.doi.org/10.1111/conl.12007

McGillivray, D. 2011. Mitigation, compensation and conservation: screening for appropriate assessment under the EU Habitats Directive. Journal of European Environmental and Planning Law 8(4):329-352. http://dx.doi.org/10.2139/ssrn.1924264

McGillivray, D. 2012. Compensating biodiversity loss: the EU Commission's approach to compensation under Art 6 of the Habitats Directive. Journal of Environmental Law 24:417-450. http://dx.doi.org/10.1093/jel/eqs007

Mikkelson, G. M. 2013. Growth is the problem; equality is the solution. Sustainability 5(2):432-439. http://dx.doi.org/10.3390/ $\underline{\text { su5020432 }}$

Milieu Ltd., N. de Sadeleer, C.-H. Born, and M. Prieur. 2009. National legislation and practices regarding the implementation of Council directive 92/43/EEC of 21 May 1992 on the conservation of natural habitats and of wild fauna and flora. European Commission, Brussels, Belgium. [online] URL: http://www. europarl.europa.eu/document/activities/cont/200910/20091013ATT62399/20091013ATT62399EN.pdf

Moilanen, A., A. J. A. van Teeffelen, Y. Ben-Haim, and S. Ferrier. 2009. How much compensation is enough? A framework for incorporating uncertainty and time discounting when calculating offset ratios for impacted habitat. Restoration Ecology 17:470-478. http://dx.doi.org/10.1111/j.1526-100X.2008.00382. $\underline{x}$

Moreno-Mateos, D., M. E. Power, F. A. Comin, and R. Yockteng. 2012. Structural and functional loss in restored wetland ecosystems. PLoS Biology 10:e1001247. http://dx.doi.org/10.1371/ journal.pbio. 1001247

Moreno-Mateos, D., V. Maris, A. Béchet, and M. Curran. 2015. The true loss caused by biodiversity offsets. Biological Conservation 192:552-559. http://dx.doi.org/10.1016/j.biocon.2015.08.016

Morris, R. K. A. 2011. The application of the Habitats Directive in the UK: compliance or gold plating? Land Use Policy 28:361-369. http://dx.doi.org/10.1016/j.landusepol.2010.04.005

Opdam, P. F. M., M. E. A. Broekmeyer, and F. H. Kistenkas. 2009. Identifying uncertainties in judging the significance of human impacts on Natura 2000 sites. Environmental Science and Policy 12:912-921. http://dx.doi.org/10.1016/j.envsci.2009.04.006

Pilgrim, J. D., and L. Bennun. 2014. Will biodiversity offsets save or sink protected areas? Conservation Letters 7(5):423-424. http:// dx.doi.org/10.1111/conl.12145 
Pilgrim, J. D., S. Brownlie, J. M. M. Ekstrom, T. A. Gardner, A. Von Hase, K. ten Kate, C. E. Savy, R. T. T. Stephens, H. J. Temple, J. Treweek, G. T. Ussher, and G. Ward. 2013. A process for assessing the offsetability of biodiversity impacts. Conservation Letters 6(5):376-384. http://dx.doi.org/10.1111/conl.12002

Quétier, F., and S. Lavorel. 2011. Assessing ecological equivalence in biodiversity offset schemes: key issues and solutions. Biological Conservation 144:2991-2999. http://dx.doi.org/10.1016/j. biocon.2011.09.002

Quétier, F., B. Regnery, and H. Levrel. 2014. No net loss of biodiversity or paper offsets? A critical review of the French no net loss policy. Environmental Science and Policy 38:120-131.

Reese, M. 2015. Habitat offset and banking - will it save our nature? Pages 483-498 in C.-H. Born, A. Cliquet, H. Schoukens, D. Misonne, and G. Van Hoorick, editors. The Habitats Directive in its EU environmental law context: European nature's best hope? Routledge, Oxford, UK.

Reid, C. T. 2011. The privatisation of biodiversity? Possible new approaches to nature conservation law in the UK. Journal of Environmental Law 23(2):203-231. http://dx.doi.org/10.1093/jel/ $\underline{\text { eqr005 }}$

Sagoff, M. 1981. Economic theory and environmental law. Michigan Law Review 79:1393-1419. http://dx.doi.org/10.2307/1288102

Sanderson, F. J., R. Pople, C. Ieronymidou, I. J. Burfield, R. D. Gregory, S. J. Willis, C. Howard, P. A. Stephens, A. E. Beresford, and P. F. Donald. 2016. Assessing the performance of EU nature legislation in protecting target bird species in an era of climate change. Conservation Letters 9:172-180. http://dx.doi.org/10.1111/ conl.12196

Schoukens, H. 2014. The ruling of the court of justice in Sweetman: how to avoid a death by a thousand cuts? ELNI Review $1: 2-12$.

Schoukens, H. 2015. Ecological restoration as the $21^{\text {st }}$ century environmental paradigm. Is EU law capable of saving our declined nature? Pages 63-87 in J. De Bruyne, M. de Potter de ten Broeck, and I. Van Hiel, editors. Policy within and through law: proceedings of the 2014 ACCA-conference Maklu, Antwerpen, Belgium.

Schoukens, H., and K. Bastmeijer. 2015. Species protection in the European Union. How strict is strict? Pages 121-146 in C.-H. Born, A. Cliquet, H. Schoukens, D. Misonne, and G. Van Hoorick, editors. The Habitats Directive in its EU environmental law context: European nature's best hope? Routledge, Oxford, UK.

Schoukens, H., and A. Cliquet. 2014. Mitigation and compensation under EU nature conservation law in the Flemish region: beyond the deadlock for development projects? Utrecht Law Review 10:194-215. http://dx.doi.org/10.18352/ulr.278

Schoukens, H., and H. Woldendorp. 2014. Juridische moeilijkheden bij proactieve natuurontwikkeling: een laatste reddingsboei voor het polderdorpje Doel? Tijdschrift voor Omgevingsrecht en -beleid 97-118.

Scott, P. 2012. Appropriate assessment: a paper tiger. Pages 103-117 in G. Jones QC, editor. The Habitats Directive: a developer's obstacle course? Hart, Oxford, UK.
Sharpston, E. 2013. Opinion in case C-258/11 Peter Sweetman and Others v. An Bord Pleanála. Court of Justice of the European Union, Luxembourg City, Luxembourg. [online] URL: http:// curia.europa.eu/juris/liste.jsf?language $=$ en \&num $=$ C-258/11

Sharpston, E. 2014. Case C-521/12 Briels and Others v. Minister van Infrastructuur en Milieu. Court of Justice of the European Union, Luxembourg City, Luxembourg. [online] URL: http:// curia.europa.eu/juris/liste.jsf?num=C-521/12

Society for Ecological Restoration (SER). 2004. The SER international primer on ecological restoration. Society for Ecological Restoration, Washington, D.C., USA. [online] URL: http://www.ser.org/resources/resources-detail-view/ser-internationalprimer-on-ecological-restoration

Stevens, C., L. Jones, E. Rowe, S. Dale, J. Hall, R. Payne, C. Evans, S. Caporn, L. Sheppard, N. Menichino, and B. Emmett. 2013. Review of the effectiveness of on-site habitat management to reduce atmospheric nitrogen deposition impacts on terrestrial habitats. CCW Science Series Report No. 1037 (part A). Countryside Council for Wales, Bangor, UK. [online] URL: http://nora.nerc. ac.uk/510481/

Suding, K. N. 2011. Toward an era of restoration in ecology: successes, failures, and opportunities ahead. Annual Review of Ecology, Evolution, and Systematics 42:465-487. http://dx.doi. org/10.1146/annurev-ecolsys-102710-145115

ten Kate, K., J. Bishop, and R. Bayon. 2004. Biodiversity offsets: views, experience and the business case. International Union for Conservation of Nature, Gland, Switzerland and Cambridge, UK and Insight Investment, London, UK. [online] URL: https:// cmsdata.iucn.org/downloads/bdoffsets.pdf

ten Kate, K., and M. Crowe. 2014. Biodiversity offsets: policy options for governments. An input paper for the IUCN Technical Study Group on Biodiversity Offsets. International Union for Conservation of Nature, Gland, Switzerland. [online] URL: http://www.forest-trends.org/documents/files/doc 4777.pdf

ten Kate, K., and J. Pilgrim. 2014. Biodiversity offsets technical study paper. IUCN Technical Study Group on Biodiversity Offsets. International Union for Conservation of Nature, Gland, Switzerland. [online] URL: http://cmsdata.iucn.org/downloads/ final biodiversity offsets paper 9nov2014 1.pdf

Tucker, G., B. Allen, M. Conway, I. Dickie, K. Hart, M. Rayment, C. Schulp, and A. Van Teeffelen. 2013. Policy options for an EU no net loss initiative, report to the European Commission. Institute for European Environmental Policy, London, UK. [online] URL: http://blogs.ec.europa.eu/orep/policy-options-for-an-eu-no-net-lossinitiative/

United Kingdom Department for Environment, Food and Rural Affairs (DEFRA). 2012. Report of the habitats and wild birds directives implementation review. United Kingdom Department for Environment, Food and Rural Affairs, London, UK. [online] URL: https://www.gov.uk/government/uploads/system/uploads/ attachment_data/file/69513/pb13724-habitats-review-report.pdf

Van Teeffelen, A. J. A., P. Opdam, F. Wätzold, F. Hartig, K. Johst, M. Drechsler, C. C. Vos, S. Wissel, and F. Quétier. 2014. Ecological and economic conditions and associated institutional challenges for conservation banking in dynamic landscapes. Landscape and 
Urban Planning 130:64-72. http://dx.doi.org/10.1016/j.

landurbplan.2014.06.004

Verschuuren, J. 2003. Effectiveness of nature protection legislation in the European Union and the United States: the birds and Habitats Directives and the Endangered Species Act. Pages 39-67 in M. Dieterich and J. van der Straaten, editors. Cultural landscapes and land use: the nature conservation-society interface. Springer, Berlin, Germany. http://dx.doi.org/10.1007/1-4020-2105-4 4

Verschuuren, J. 2010. Climate change: rethinking restoration in the European Union's birds and Habitats Directive. Ecological Restoration 28:431-439. http://dx.doi.org/10.3368/er.28.4.431

Wandesforde-Smith, G., and N. S. J. Watts. 2014. Wildlife conservation and protected areas: politics, procedure, and the performance of failure under the EU Birds and Habitats Directive. Journal of International Wildlife Law 17:62-80. http:// dx.doi.org/10.1080/13880292.2014.866414

Woodstock, B. A., I. N. Vogiatzakis, D. B. Westbury, C. S. Lawson, A. R. Edwards, A. J. Brook, S. J. Harris, K. A. Lock, N. Maczey, G. Masters, V. K. Brown, and S. R. Mortimer. 2010. The role of management and landscape context in the restoration of grassland phytoplahgous beetles. Journal of Applied Ecology 47:366-376. http://dx.doi.org/10.1111/j.1365-2664.2010.01776.x

Zijlmans, J. M. I. J., and H. E. Woldendorp. 2014. Compensation and mitigation: tinkering with Natura 2000 protection law. Utrecht Law Review 10:172-193. http://dx.doi.org/10.18352/ ulr. 277 